\title{
LANDSLIDE DETECTION AND SUSCEPTIBILITY MAPPING USING GEOLOGICAL AND REMOTE SENSING DATA: A CASE STUDY OF AZAD KASHMIR, NW SUB-HIMALAYAS
}

\author{
Muhammad ZEESHAN * and Kamran MIRZA
}

Institute of Geology, University of the Punjab, Lahore, Pakistan

*Corresponding author's e-mail: zeeshan.geo@pu.edu.pk

\begin{tabular}{l} 
ARTICLE INFO \\
\hline Article history: \\
Received 14 November 2020 \\
Accepted 1 January 2021 \\
Available online 19 January 2021 \\
\hline
\end{tabular}

Keywords:

Geology

Landslide

Remote Sensing

Himalaya

\begin{abstract}
Azad Kashmir has undergone sever landslide episodes in the past. The main reasons behind the occurrence of landslides in this area are heavy rainfall, weak geological strata, seismic zones and active faults. Several episodes of roads blockage due to landslide is one of the major problem in this area, therefore, this study is carried out for landslide susceptibility analysis along the roads of Kotli to Trar Khel, Azad Kashmir, NW Sub-Himalayas. Geographic information system (GIS) is used to interpret remote sensing, geological strata and topographical data. Total ten anthropogenic and physical factors (aspects, fault, lithology, drainage density, curvature, distance to roads, landuse landcover, slope, seismic and elevation) were examined by Multi-criteria Decision Analysis (MCDA) technique. The thematic layers of all factors were prepared for the preparation of the final susceptibility map by using a weighted overlay method (WOM). The susceptibility map classified the study area into four susceptible classes of low, moderate, high and very high. The spatial analysis and result outcomes depicted that active faults, slope gradient and landuse landcover may facilitate landslide phenomena. The results were verified by landslide density analyses (LDA), receiver operator characteristics (ROC) and area under curve (AUC) with predictive accuracy of $77 \%$ that is rated as satisfactory by many researchers.
\end{abstract}

\section{INTRODUCTION}

In mountainous areas, the landslide is a natural disaster that can lead to colossal economicinfrastructure and social-human lives (Regmi et al., 2010; Vallejo and Ferrer, 2011; Bacha et al., 2018; Khan et al., 2019). Landslide is the third most disastrous natural hazard that can cause very severe causalities (Zillman, 1999; Feizizadeh and Blaschke, 2011). Landslides are categorized on the bases of material types and movement (Cruden and Varnes, 1996). The movements in natural slopes can be initiated by several factors e.g. slope angle, earthquake, lithology of strata, precipitation etc. (Cano and Tomás, 2013; Oh and Lu, 2015).

Azad Kashmir is situated in tectonically active zones that caused severe damages due to earthquakes. The Northern area of Pakistan is one of the most precarious zones of the world due to weak geological strata, heavy monsoon rainfall and snowfall, steep slopes and seismically active area (Basharat et al., 2016). Many researchers (Basharat and Rohn, 2015; Shafique et al., 2016; Ali et al., 2019) reported that various landslides were triggered in Kashmir during the earthquake of 2005. Petley (Petley et al., 2005) reported death tolls of 26000 due to the Kashmir earthquake. Hattian Bala landslide was triggered by the Kashmir earthquake that is situated at a distance of $30 \mathrm{~km}$ approximately from the study area (Dunning et al., 2007; Basharat et al., 2012). The surrounding area of Balakot was badly affected in terms of life loss due to massive landslides (Jadoon et al., 2015). Moreover, in study area, landslide events may cause very severe loss of human life, communication means (Highways, telecommunication), buildings/structures and industry, etc. For that reason hazard zonation/susceptibility mapping, for the forecasting of landslide events is one of the important subject to mitigate the severe damages by proper strategies, preparation and management.

Landslides inventories and susceptibility maps have a vital role in the planning of landslide hazards mitigation (Basharat et al., 2016; Erener et al., 2016; Bacha et al., 2018). Landslide inventories to assess landslide susceptibility zones can be develop by using data of satellite images and aerial photos with the help of Geographic Information System (GIS) (Chalkias et al., 2014; Shafique et al., 2016; Wang and LI, 2017). Landslide susceptibility assessments are based on qualitative, quantitative and semi-quantitative approaches used by various researchers for landslide susceptibility mapping (Aleotti and Chowdhury, 1999; Fell et al., 2008; Psomiadis et al., 2020). Qualitative 
Table 1 Detail of methods, parameters, and study area of previous works conducted by researchers for landslide susceptibility mapping in surrounding areas of study area.

\begin{tabular}{|c|c|c|c|}
\hline Authors & Study Area & *Parameters for Weight & Method \\
\hline Kamp et al., (2008) & Muzaffarabad District & $1,2,3,4,5,6,7,8,9$ & $\begin{array}{l}\text { Multi-Criteria Evaluation and } \\
\text { Analytical Hierarchy Process }\end{array}$ \\
\hline Ahmed et al. (2014) & Upper Indus watershed & $1,3,4,8,10,11,12,13,14$ & $\begin{array}{l}\text { Weighted Overlay Method and } \\
\text { Fuzzy Logic }\end{array}$ \\
\hline $\begin{array}{l}\text { Basharat et al. } \\
(2016)\end{array}$ & BalaKot Tehsil & $1,2,3,4,5,7,8,10,15$ & $\begin{array}{l}\text { Multi-Criteria Evaluation and } \\
\text { Analytical Hierarchy Process }\end{array}$ \\
\hline $\begin{array}{l}\text { Kanwal et al. } \\
(2016)\end{array}$ & $\begin{array}{l}\text { Shigar and Shyok Basin } \\
\text { in Karakoram range }\end{array}$ & $1,3,4,5,6,7,8$ & $\begin{array}{l}\text { Analytical Hierarchy Process } \\
\text { based heuristic approach }\end{array}$ \\
\hline Khan et al. (2018) & $\begin{array}{l}\text { Haramosh, Bagrote and } \\
\text { Nagar valley }\end{array}$ & $1,3,4,5,6,7,8,10,16$ & Frequency Ratio \\
\hline Bacha et al. (2018) & Hunza-Nagar valley & $1,3,4,5,6,7,8$ & $\begin{array}{l}\text { Weight of Evidence and } \\
\text { Frequency Ratio }\end{array}$ \\
\hline Rahim et al. (2018) & Ghizer District & $\begin{array}{l}1,2,3,4,5,7,8,13,16 \\
11,17,18\end{array}$ & $\begin{array}{l}\text { Analytical Hierarchy Process and } \\
\text { Weighted Linear Combination }\end{array}$ \\
\hline Ali et. al. (2019) & Karakoram Highway & $1,2,3,4,5,6,8,10,12,11$ & $\begin{array}{l}\text { Analytical Hierarchy Process and } \\
\text { Weighted Overlay Method }\end{array}$ \\
\hline
\end{tabular}

approach is very useful as it is based on the expert judgement including detailed information of study area. Quantitative approach includes numerical ratings for controlling factors based on the information of previously occurred landslide events. Moreover, semiquantitative approach like analytical hierarchy process (AHP) is very useful technique if we have excellent understanding with the physical and anthropogenic parameters of the study area. Therefore, semiquantitative approach is implemented in this study to get better accuracy. The multiple-criteria decision analysis (MCDA) is a combination of weighted overlay method (WOM) and analytical hierarchy process (AHP) and has better accuracy to detect landslide hazards (Kamp et al., 2008; Ahmed, 2015; Basharat et al., 2016; Kanwal et al., 2016).

The compilation of landslide inventory provide the systematic information of landslides (Spiker and Gori, 2000; Chacon et al., 2006). Landslide susceptibility analyses for Balakot, NW SubHimalayas Pakistan was conducted by processing the data of topographic, remote sensing and geology by using geographic information system (GIS) (Basharat et al., 2016). Thematic data layers were developed by using nine causative factors and landslide susceptibility map was produced in GIS. Geospatial techniques were used to identify the landslide susceptible villages along Kalsubai region and concluded that 9 villages are fall in very high risk, 13 villages in high risk, 12 villages in moderate risk, 11 villages in low risk and 14 villages fall in the category of very low risk zones (Gawali et al., 2017). Landslide susceptibility study for upper Indus river basin was undertaken by using GIS techniques and verified by landslide inventory mapping and historical data (Ahmed et al., 2014). One of the challenging factors for geotechnical engineers to assess the safety of road cut soil slopes along the national highway and in hilly areas stability of slopes is required during the construction of roads. The main focus is to mitigate the risk of slope failure during the design of roads to avoid any loss of life and infrastructures (Rafek et al., 2016). Along the various roads of Azad Kashmir, the landslide is one of the most hazardous phenomena but relatively fewer studies have been carried out to investigate the critical zones especially along the roads of Azad Kashmir. Landslide susceptibility studies conducted in the surrounding areas of study area by several researchers are tabulated in Table 1.

This study presents the susceptibility analyses of areas from Azad Kashmir to minimize the damages by detecting landslide events that may occur in the future. Several geologists have contributed to study the slope failure assessments but no proper study regarding detailed evaluation of the slopes in addition to GIS, remote sensing and statistical analyses in the study area has been carried out so far. This research will demarcate different zones that may cause various casualties in the future. One of the landslides was observed near Kotli during field visit that may cause the blockage of road and traffic communication, therefore, this study will play a vital role to identify the landslide susceptible zones.

\section{STUDY AREA}

The study area lies in NW Sub-Himalayas and comprised of two districts (Kotli and Poonch) of Azad Kashmir. The designated study area is a mainly mountainous region that covers a total area of 228 square kilometers and road stretch of 71.4 kilometers was selected from Kotli to Tata Pani, Tata Pani to Hajira and Hajira to Trar Khel. The location map with coordinates of the bounded study area is presented in Figure 1. Approximately May to October are the 


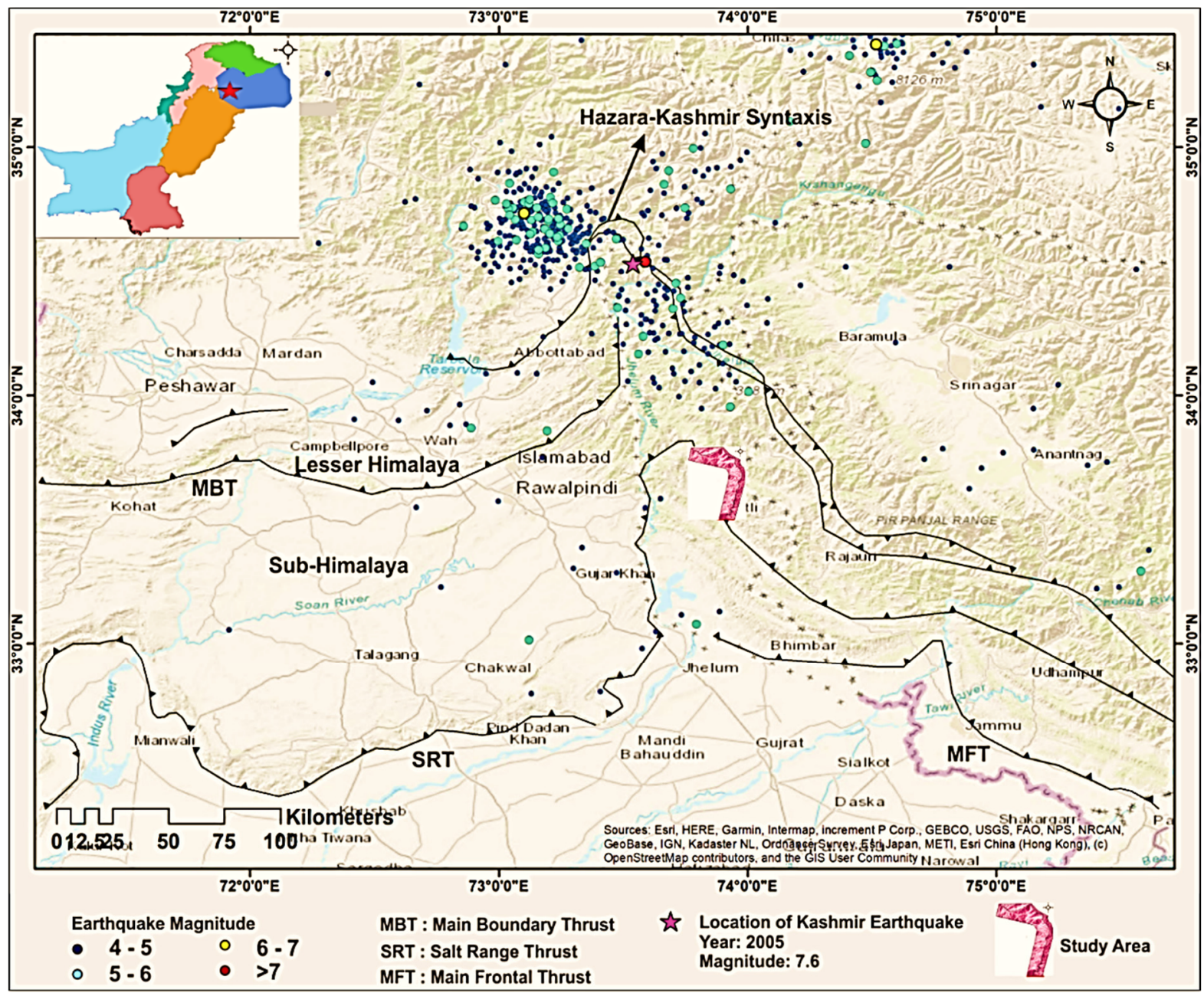

Fig. 1 Overview of tectonic setting in surrounding of the study area including active fault lines and earthquake locations with magnitude (USGS Earthquake Catalog, 2020) (Modified after Riaz et al., 2018).

months of highest temperature with a maximum of 75- $89{ }^{0} \mathrm{~F}$ and November to April are the months of cold weather. The maximum elevation of the study area calculated from the digital elevation model is 1800 to $2100 \mathrm{~m}$. Most of the rainfall episodes repeat in the study area for the whole year with a maximum average rainfall of $172 \mathrm{~mm}$ ( $6.8 \mathrm{inch})$.

The tectonically study area is bounded by HKS in the southwest and MBT in the northeast. NangaParbat Syntaxis and Hazara Kashmir Syntaxis (HKS) were developed on the north-western margin of the Himalayan orogenic belt. The study area situated near the Hazara Kashmir Syntaxis (HKS) as shown in Figure 1. The main tectonic features like thrusts and faults surrounded by the study area are Salt range Thrust/Main frontal thrust, Main Boundary Thrust, Jhelum Fault and Muzaffarabad Fault. Geological mapping of the study area was assessed based on the maps of the Geological Survey of Pakistan (2004) (Sheet No. 43, G/14, Scale 1:50,000), satellite images and field observations. Precambrian to Quaternary age units are observed in the study area, these stratigraphical units are highly deformed due to the presence of active deformation zones connect with major thrusts and faults. The separation of Sub Himalayan molasses (at the core of the HKS) and premolasse Lesser Himalayan (at Limbs of HKS) are demarcated by Main Boundary Thrust (MBT). Rocks from Cenozoic and Precambrian age are prevailing in the study area and their representation is marked on the geological map. Murree Formation of Early Miocene and Kamlial Formation of Middle to Early Miocene belong to the Rawalpindi group which represents the marine to the continental transition of sedimentation after the closure of Neotethys. The stratigraphic units present in the study are explained from younger units towards older units, respectively. Mirpur Conglomerates of Pleistocene age comprises poorly sorted conglomerates including pebbles and boulders of sedimentary, igneous and metamorphic rocks indurated in sandy and clayey matrix. Dhok Pathan Formation of Early Pliocene to late Miocene age belongs to Siwalik Group that consists of sandstone of grayish color, fine to medium grained, 
medium to thick bedded along with silty clay and in upper part lenses of conglomerates are present. Dhok pathan formation overlies the Rawalpindi Group in the study area. Murree Formation composed of dark red to purple and greenish gray sandstone and siltstone beds and purple to reddish brown mudstone along with lenses of conglomerates. Similarly, Kamlial Formation comprised of purple greyish to reddish medium to coarse grained sandstone with interbeds of mudstone and conglomerates. Patala Formation of Paleocene age comprised of shale and nodular, crystalline, dark gray to light 3 brown limestone with underlies the Rawalpindi group in the study area. Muzaffarabad Formation (Proterozoic age) consists of light to dark gray cherty dolomite in the lower part overlain by white to brownish fine-grained quartzite.

\section{MATERIALS AND METHODS}

\subsection{DATA COLLECTION}

The development of landslide susceptibility map based on GIS techniques included several segments like the selection of the most relevant causative factors that can play important role in triggering of the landslide, development of database by the production of data layers, allocation of numerical weights to all factors and the computation of landslide susceptibility model with its validation (Sarkar and Kanungo, 2004). Total of ten thematic layers of causative factors (aspects, fault, lithology, drainage density, curvature, distance to roads, landuse landcover, slope, seismic, elevation) were planned with respect to study area to develop the final susceptibility map. Therefore, Digital Elevation Model (DEM) was used to derive geomorphological factors (e.g. slope, aspect, elevation, curvature) and drainage. In this regard, Advanced Land Observing Satellite (ALOS) PALSAR based DEM $(12.5 \times 12.5 \mathrm{~m})$ was gathered to collect the above mentioned parameter of high precision with the help of ArcGIS software. Other ancillary data including geological maps, faults, roads, seismic points were congregated by using map sheets of Geological Survey of Pakistan (GSP) in line with field verifications and satellite imageries by projecting all the collected data sheets in ArcGIS for georeferencing using Universal Transverse Mercator (UTM-43N) and World Geodetic System (WGS-1984). Furthermore, supervised classification in GIS and semi-automatic classification plug-in (SCP) of QGIS 2.18's was used for the extraction of landuse landcover by acquired Satellite images of Landsat 8 from the web portal of United States Geological Survey (USGS).

\subsubsection{PREPARATION OF THEMATIC MAPS}

Thematic layers of various causative factors were prepared by using raster data in GIS with specific classifications. Thematic layer of drainage density was prepared by using Arc hydro tool in GIS. A tool of multi ring buffer was used to create a buffer of various distances around the factors of faults, roads and seismic points. Moreover, all vector layers of various factors were converted into a digital raster data system to prepare different classified thematic layers to derive the input parameters for the production of landslide susceptibility map by using a weighted overlay method in GIS.

\subsection{METHODOLOGY}

The initial step for the production of landslide susceptibility map is to gather information of landslides and preparation of landslides inventory based on the collected information from field, aerial photographs and satellite imageries. In this study, information of the number of landslide and unstable slopes were collected from the field visits and marked on the map using ArcGIS for further verification of developed landslide susceptibility map by using analytical hierarchy process (AHP) with weighted overlay method.

\subsubsection{LANDSLIDE INVENTORY}

A landslide inventory map plays a vital role to get all relevant information about the landslides events. In AHP, the acquaintance with the causes of landslides deriving factors is very important to assign the ratings, therefore, landslide inventory maps are prepared to determine the impact of geological strata, tectonics (faults etc.), hydrological and geomorphological factors on the occurrence of the landslide. Inventory maps can be prepared on the basis of gathered information from satellite images, field visits, previous landslide events, data from relevant publications and aerial photographs (van Westen et al., 2006; Kayastha et al., 2013b). The landslide events based on remote sensing can also be identified by the comparison of geomorphological features, spatial characteristics, contrast and shape (Kumar et al., 2018). In this study, the landslide inventory map was produced by using field data and satellite images (Fig. 2). In unstable areas, the landslide features including evidence of previous movements, tension cracks, escarpment faces, springs, backward rotation of trees and boundary of slid masses were recorded. Information about the history and frequency of slope movements was sought in the field together with the knowledge of causative factors and photographs of various landslides are shown in Figure 3. The landslide inventory was utilized for spatial analyses as well as to check the accuracy of developed susceptibility map.

\subsubsection{WEIGHTS FACTOR ANALYSES USING ANALYTICAL HIERARCHY PROCESS (AHP)}

In landslide susceptibility mapping analytical hierarchy process (AHP) is a multi-criteria decision making approach in which preference values are assigned to all landslide contributing factors by spatial analysis. The approach of the analytical hierarchy process (AHP) was proposed by Saaty in 1970 by using pair wise comparison between various factors to get values of priorities based on expert experience. In 

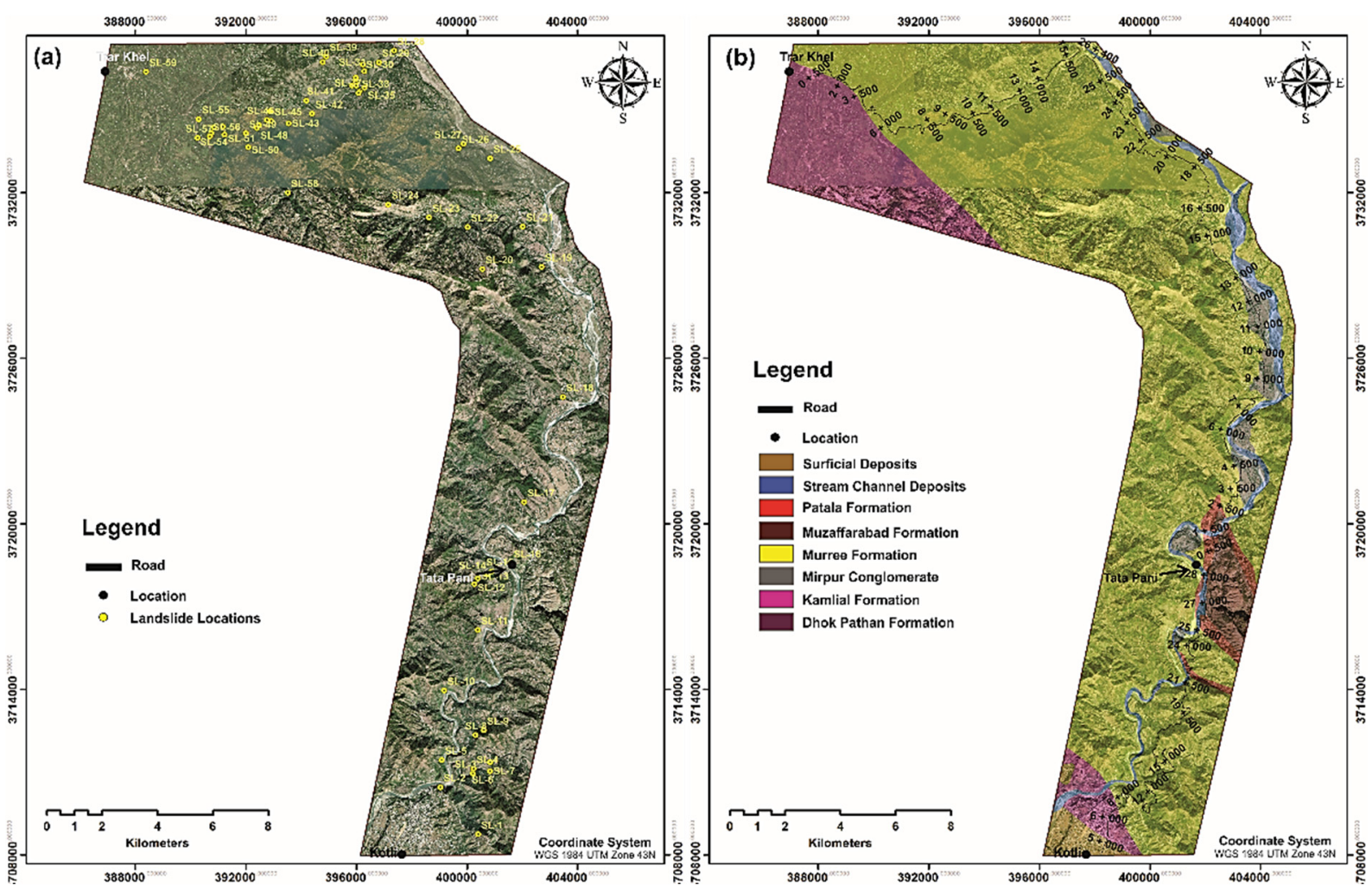

Fig. 2 (a) Location of the Landslides overlaid by the Landsat image that was downloaded from ArcGIS Base Map, (b) Geology overlaid by Landsat image showing the main landslide triggering geological strata.

landslide susceptibility mapping, a comparison of all causative factors is involved on the basis of pair wise matrix (Saaty, 1980). In the assessment of landslide, AHP is one of the useful technique because all factors can be included in the process of discussion, wellstructured decision related to the problem, inclusion of expert experience, justifiable decision rules, the calculated weight of each causative factor based on the calculations of eigenvector decision matrix can be obtained and any conflicts in the process of the decision can be rectified after identification (Kumar et al., 2018). The ratings of 1 to 9 are assigned to all factors according to their relative importance with increasing impact from equal importance (1) to extreme importance (9). In this study, pair wise comparison of all factors (aspects, fault, lithology, drainage density, curvature, distance to roads, landuse landcover, slope, seismic, elevation) is carried out by using pairwise comparison matrix and ratings of 1-9 according to Table 2 are assigned to all those factors on $y$-axis when these factors have greater importance as compared to the factors along $\mathrm{x}$-axis. On the other hand, the assigned values rated between $1 / 2$ to $1 / 9$ for factors having more importance along the x-axis as compare to factors of y-axis (Saaty, 2008). The values were assigned by using field information, spatial analyses and expert opinion. Thus, the weights of all factors in the form of eigenvector were obtained based on matrix comparison.
The calculation of consistency index and consistency ratio is one of the important part of the AHP (Saaty, 1980). Inconsistencies in the process of allocation of ratings to all parameters can be avoid by using the Consistency Ratio (CR) (Basharat et al., 2016; Kanwal et al., 2016; Pourghasemi and Rossi, 2017; Ali et al., 2019). Consistency ratio can be formulated as:

$\mathrm{CR}=\mathrm{CI} / \mathrm{RI}$

Where, $\mathrm{CI}$ is the Consistency index and RI is stand for Random index. CI can be calculated by using this expression.

$\mathrm{CI}=\frac{\lambda_{\max }-\mathrm{n}}{\mathrm{n}-1}$

Where, $\lambda_{\max }$ is the maximum eigenvalue of the matrix and $\mathrm{n}$ is the total number of controlling factors (Zhou et al., 2016). Saaty, (1990) proposed that CR should be less than 0.1 for validation of consistent decision, $\mathrm{CR}$ values greater than 0.1 represents inconsistency in the decision and indicate the requirement of revision in the judgment. Therefore, in the present study CR values less than 0.1 were accepted that represents consistency in the decision and values greater than 0.1 were excluded. Therefore, CR values for subclasses of all causative factors were calculated and prioritized by assigned ratings based on spatial analysis (Table 2). The influence of curvature was easily scaled with expert judgment because of only two subclasses. 

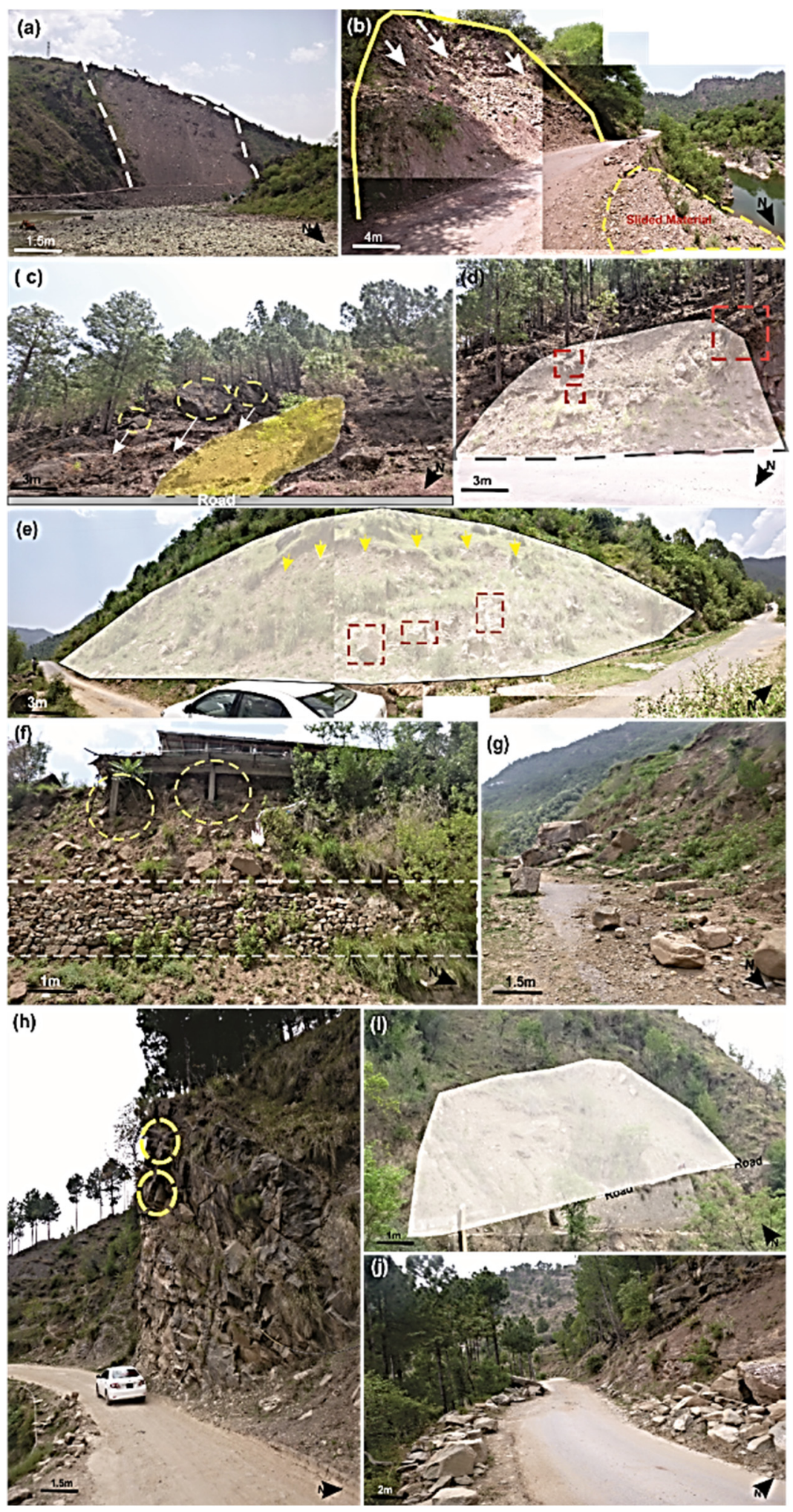

Fig. 3 (a) Debris flow near Kotli due to slips in overburden, (b) Debris flooding the road directly, (c) Yellow shade is for the slide in material and yellow dotted circles are locating the possible movement of rockfall towards road, (d) Slide in slope material and exposed roots of trees due to movement, (e) Whitish shade representing the debris flow along with rockfall, (f) Foundation failure due to downward movement of debris, (g) Blockage of road due to severe rockfall, (h) Rockfall from the outcrop of sandstone, (i) Debris flow of overburden towards road, retaining wall is providing support to road against failure, (j) Rockfall flooding the road. (For locations see symbols (stars) “T,U,X,Y,Z” in Fig. 6a). 
Table 2 Pair-wise comparison matrix of causative factors.

\begin{tabular}{|c|c|c|c|c|c|c|c|c|c|c|}
\hline \multirow{2}{*}{\multicolumn{2}{|c|}{ Causative Factors }} & \multicolumn{8}{|c|}{ Pair-wise comparison matrix } & \multirow{2}{*}{$\begin{array}{l}\text { Weight } \\
\text { (\%) }\end{array}$} \\
\hline & & 1 & 2 & 3 & 4 & 5 & 6 & 7 & 8 & \\
\hline \multicolumn{11}{|c|}{ Aspect } \\
\hline 1 & North & 1 & & & & & & & & 2.51 \\
\hline 2 & Northeast & 4 & 1 & & & & & & & 6.42 \\
\hline 3 & East & 6 & 1 & 1 & & & & & & 9.49 \\
\hline 4 & Southeast & 8 & 6 & 5 & 1 & & & & & 28.81 \\
\hline 5 & South & 9 & 7 & 3 & 1 & 1 & & & & 26.70 \\
\hline 6 & Southwest & 7 & 5 & 1 & $1 / 3$ & $1 / 3$ & 1 & & & 13.67 \\
\hline 7 & West & 4 & 1 & 1 & $1 / 4$ & $1 / 2$ & $1 / 2$ & 1 & & 8.39 \\
\hline \multirow{2}{*}{\multicolumn{2}{|c|}{ Northwest }} & 1 & $1 / 2$ & $1 / 3$ & $1 / 4$ & $1 / 6$ & $1 / 3$ & $1 / 2$ & 1 & 4.01 \\
\hline & & & & & & & & & \multicolumn{2}{|c|}{$\mathrm{CR}=0.063$} \\
\hline \multicolumn{11}{|c|}{ Elevation } \\
\hline 1 & $0-500$ & 1 & & & & & & & & 6.18 \\
\hline 2 & $501-1000$ & 6 & 1 & & & & & & & 55.66 \\
\hline 3 & $1001-1500$ & 5 & $1 / 3$ & 1 & & & & & & 24.55 \\
\hline \multirow[t]{2}{*}{4} & $1501-2000$ & 3 & $1 / 5$ & $1 / 2$ & 1 & & & & & 13.60 \\
\hline & & & & & & & & & \multicolumn{2}{|c|}{$\mathrm{CR}=0.059$} \\
\hline \multicolumn{11}{|c|}{ Distance to Fault } \\
\hline 1 & $0-200$ & 1 & & & & & & & & 27.49 \\
\hline 2 & $201-400$ & 3 & 1 & & & & & & & 54.83 \\
\hline 3 & $401-600$ & $1 / 4$ & $1 / 6$ & 1 & & & & & & 10.18 \\
\hline \multirow[t]{2}{*}{4} & $601-800$ & $1 / 4$ & $1 / 5$ & $1 / 2$ & 1 & & & & & 7.50 \\
\hline & & & & & & & & & & $R=0.088$ \\
\hline & ological Strata & & & & & & & & & \\
\hline 1 & Surficial Deposits & 1 & & & & & & & & 8.09 \\
\hline 2 & Mirpur Conglomerates & $1 / 2$ & 1 & & & & & & & 6.12 \\
\hline 3 & Kamlial Formation & 5 & 4 & 1 & & & & & & 23.52 \\
\hline 4 & Murree Formation & 7 & 6 & 2 & 1 & & & & & 38.61 \\
\hline 5 & Patala Formation & 2 & 3 & $1 / 3$ & $1 / 6$ & 1 & & & & 10.08 \\
\hline 6 & Muzaffarabad Formation & $1 / 2$ & $1 / 2$ & $1 / 6$ & $1 / 8$ & $1 / 2$ & 1 & & & 5.40 \\
\hline 7 & Dhok Pathan Formation & $1 / 3$ & $1 / 2$ & $1 / 6$ & $1 / 8$ & $1 / 2$ & $1 / 3$ & 1 & & 4.87 \\
\hline 8 & Chinji Formation & $1 / 3$ & $1 / 2$ & $1 / 4$ & $1 / 7$ & $1 / 3$ & $1 / 2$ & $1 / 4$ & 1 & 3.31 \\
\hline & & & & & & & & & & $R=0.086$ \\
\hline & aduse landcover & & & & & & & & & \\
\hline 1 & Urban & 1 & & & & & & & & 20.73 \\
\hline 2 & Water & 1 & 1 & & & & & & & 17.79 \\
\hline 3 & Vegetation & $1 / 6$ & $1 / 3$ & 1 & & & & & & 5.46 \\
\hline 4 & Rock/Soil & 4 & 3 & 8 & 1 & & & & & 56.02 \\
\hline & & & & & & & & & & $R=0.061$ \\
\hline & ainage Density & & & & & & & & & \\
\hline & Ver Low Density & 1 & & & & & & & & 4.89 \\
\hline 2 & Low Density & 2 & 1 & & & & & & & 6.91 \\
\hline 3 & Medium Density & 3 & 4 & 1 & & & & & & 15.02 \\
\hline 4 & High Density & 5 & 4 & 2 & 1 & & & & & 23.04 \\
\hline & Very High Density & 7 & 6 & 5 & 3 & 1 & & & & 50.14 \\
\hline & & & & & & & & & & $R=0.068$ \\
\hline & tance to Roads & & & & & & & & & \\
\hline 1 & $0-50$ & 1 & & & & & & & & 60.796 \\
\hline 2 & $51-100$ & $1 / 3$ & 1 & & & & & & & 27.210 \\
\hline 3 & $101-150$ & $1 / 4$ & $1 / 3$ & 1 & & & & & & 11.994 \\
\hline & & & & & & & & & & $z=0.087$ \\
\hline & pe & & & & & & & & & \\
\hline 1 & $0-15$ & 1 & & & & & & & & 10.18 \\
\hline 2 & $15-30$ & 5 & 1 & & & & & & & 33.95 \\
\hline 3 & $30-45$ & 3 & 2 & 1 & & & & & & 39.39 \\
\hline 4 & $45-60$ & 2 & $1 / 4$ & $1 / 4$ & 1 & & & & & 11.55 \\
\hline 5 & $>60$ & $1 / 3$ & $1 / 6$ & $1 / 5$ & $1 / 4$ & 1 & & & & 4.93 \\
\hline & & & & & & & & & & $R=0.076$ \\
\hline & smicity & & & & & & & & & \\
\hline & X-IX & 1 & & & & & & & & 49.73 \\
\hline 2 & VIII-VII & $1 / 2$ & 1 & & & & & & & 27.99 \\
\hline 3 & VI-IV & $1 / 4$ & $1 / 2$ & 1 & & & & & & 16.34 \\
\hline 4 & III-I & $1 / 6$ & $1 / 5$ & $1 / 4$ & 1 & & & & & 5.95 \\
\hline & & & & & & & & & & $R=0.046$ \\
\hline
\end{tabular}


Table 3 Weights of all controlling factors based on pairwise comparison matrix.

\begin{tabular}{|c|c|c|c|c|c|c|c|c|c|c|c|c|}
\hline \multirow{2}{*}{\multicolumn{2}{|c|}{ Causative Factors }} & \multicolumn{10}{|c|}{ Pair-wise comparison matrix } & \multirow{2}{*}{ Weights } \\
\hline & & 1 & 2 & 3 & 4 & 5 & 6 & 7 & 8 & 9 & 10 & \\
\hline 1 & Aspect & 1.00 & & & & & & & & & & 2.33 \\
\hline 2 & Elevation & 2.00 & 1.00 & & & & & & & & & 3.35 \\
\hline 3 & Distance to Fault & 9.00 & 7.00 & 1.00 & & & & & & & & 21.09 \\
\hline 4 & Geological Strata & 5.00 & 2.00 & $1 / 4$ & 1.00 & & & & & & & 8.47 \\
\hline 5 & Landuse landcover & 9.00 & 8.00 & 1.00 & 7.00 & 1.00 & & & & & & 20.12 \\
\hline 6 & Drainage Density & 4.00 & 2.00 & $1 / 3$ & $1 / 3$ & $1 / 5$ & 1.00 & & & & & 5.18 \\
\hline 7 & Distance to Roads & 3.00 & 2.00 & $1 / 3$ & $1 / 3$ & $1 / 6$ & 2.00 & 1.00 & & & & 5.98 \\
\hline 8 & Slope & 7.00 & 6.00 & $1 / 2$ & 3 & 2.00 & 3.00 & 5.00 & 1.00 & & & 20.34 \\
\hline 9 & Curvature & $1 / 3$ & 0.33 & $1 / 4$ & $1 / 6$ & $1 / 7$ & $1 / 3$ & $1 / 5$ & $1 / 9$ & 1.00 & & 1.93 \\
\hline 10 & Seismicity & 5.00 & 3.00 & $1 / 3$ & 2.00 & 1.00 & 3.00 & 2.00 & $1 / 3$ & 7.00 & 1.00 & 11.22 \\
\hline
\end{tabular}

Finally, at the completion, each factor was assigned by a specific weight (Table 3) and CR value remained below 0.1 that represents the consistency, reliability and unbiasedness in the judgments of assigned weighted criteria.

\subsubsection{LANDSLIDE CAUSATIVE FACTORS AND SPATIAL DISTRIBUTION ANALYSES}

The causes and failure mode of landslides varies according to different locations/ points. The inventory of 59 landslides was prepared for study area and utilized in spatial analysis and verification of susceptible map. The main factors involved in the failure of landslides are: topographical, geological, geomorphological etc. In this study total ten factors were examined that mainly caused landslide failure due to the geomorphological, topographical and geological conditions of the study area. The raster files of all causative factors were generated and reclassified based on spatial analysis (Fig. 5) and all factors are discussed below in detail.

\section{LITHOLOGY}

The lithology and geological structures always play a very important role in the occurrences of landslides. Competent lithology with high strength of rock or soil can resist or reduce the events of landslides and on the other hand, poor lithology with weak strength can host disastrous landslides occurrences and may cause damages of human life, infrastructures, communication means and economy of the country. In various studies (Yalcin et al., 2011; Sharma and Mehta, 2012) lithology has given greater importance in landslide triggering phenomena. In this study, maps of the Geological Survey of Pakistan (Sheet No. 43, G/14, Scale 1:50,000) have been used for the extraction of geological contacts and also verified in the field visits where it was possible. The geological map (Fig. 4a) revealed that a major part of Murree Formation is encountered in the study area that consists of shale, sandstone, siltstone, mudstone and conglomerates and most of the road cuts are in this strata. The Murree Formation rock units show both brittle and ductile deformation. Competent lithologies have undergone through brittle deformation while soft lithologies through ductile deformation.

\section{SLOPE ASPECT}

Aspects of slopes represent the trends of highest slopes in cardinal directions (0-360 degree, clockwise) and investigated by several researchers (Akgun et al., 2008; Kayastha et al., 2013a). Aspects with respect to rainfall, light of sun and drying winds may also consider as controlling factors in landslide failure due to sunshine effect with respect to weathering process and moisture content of slope material (Awawdeh et al., 2018). The parameters of aspect were extracted from DEM by using ArcGIS software and classified the study area into eight classes (Fig. 4b). The values of classified classes are given as: North (0-22.5), Northeast (22.5-67.5), East (67.5-112.5), Southeast (112.5-157.5), South (157.5-202.5), Southwest (202.5-247.5), West (247.5-292.5), Northwest (292.5337.5). Moreover, the difference between lowest and highest elevation points is referred to as elevation or relative relief. Most of the landslides occur in high relief areas (Kavzoglu et al., 2014).

\section{SLOPE DEGREE}

The degree of slope plays a vital role in triggering landslides and an important factor to analyze it for the landslide susceptibility map and frequently used in landslide studies (Goetz et al., 2015; Pham et al., 2017). As this is already discussed in the geological setting, a major portion of the study area is comprised of Murree Formation that consists of relatively weak strata. Moreover, orientations of discontinuities are an important triggering factor in slope failure in rock outcrops along with the angle of slopes. As a result of steep slopes, the shear strength of underneath weak strata (soil or rock) becomes reduced (Pradhan et al., 2010) and caused the occurrence of the landslide in the form of toppling, wedge failure, circular failure, debris flow, rock fall, etc. Therefore, angle of slope varies from 0-90 degree, from which slope surfaces near to zero degree $\left(0^{\circ}\right)$ slope becomes more gentle (safe) and increase in slope degree make slopes steeper (unstable) along with other 
causative failure factors. The study area is comprised of hills with various degrees of slopes and also verified in the field, therefore, slopes are categorized in five classes (Fig. 4c) in which values of slope degrees varied from 0 to $70^{\circ}$. The ranges of classified classes are: $0-15^{\circ}$ (gentle slope), $16-30^{\circ}$ (Moderate gentle slope), $31-45^{\circ}$ (Steep slope), $46-60^{\circ}$ and $>60^{\circ}$ (Very steep slopes). The landslide occurrence is associated with the high slopes, so most of the landslides or slope failure may occur in the category of Steep to Very steep slopes. Moreover, gentle and moderate slopes behave like near to stable with other supportive slope stability factors.

\section{DRAINAGE DENSITY AND ELEVATION}

Drainage density represents the hydrological condition of the study area by calculating the length of stream river in the area that represents the faster flow of surface water and less rate of water infiltration in earth surface (Demir et al., 2013; Kumar et al., 2018). In this study, Arc hydro Tools of ArcGIS software and DEM were used to prepare a drainage density map and dendritic type of drainage pattern was found in the study area. Total five classes of drainage density have been classified by using spatial analysis and expert knowledge (Fig. 4d) and named as Very Low Density, Low Density, Medium Density, High Density and very High Density. In the study area, the elevation is subdivided into four classes and the values are ranged from 0-500 m, 500-1000 m, 1000-1500 and 1500$2000 \mathrm{~m}$ (Fig. 4e).

\section{$\underline{\text { ROADS MAP }}$}

In this study, slope susceptibility mapping is especially emphasized along the roads of Districts Kotli and Poonch. The road segments are classified in three sections from Kotli to Tata Pani, Tata Pani to Hajira and Hajira to Trar Khel. Road cutting is one of the causative factors of landslides or slope failure along the roads of the study area. The distance from roads is classified in three classes of $0-50 \mathrm{~m}$, 51- $100 \mathrm{~m}, 101-150 \mathrm{~m}$ by using multi ring buffer tool in ArcGIS (Fig. 4f).

\section{CURVATURE}

The topographical morphology represented by curvature and has a relation with the hydrological conditions with respect to the occurrences of the landslide. Curvature represents the slope's shape in the form of convex and concave (Pourghasemi and Kerle, 2016). The values of curvatures are also extracted from DEM by using the tool of Curvature in ArcGIS software and classifies into two classes (Fig. 4g). The evaluated data represents two sets of data (negative and positive) and if values of curvatures are positive then the slope is upwardly convex and negative values will show the concave shape of the slope (Ali et al., 2019). Curvature has a relation with hydrology because retained water for a longer time may cause the occurrence of landslide due to an increase in pore water pressure.

\section{FAULTS AND SEISMOLOGY}

Faults are the major hazardous tectonic feature in any area of the earth. Geometry and rupture of faults have a great influence on the occurrence of landslides (Mahmood et al., 2015). Therefore, movements along fault lines can cause severe disastrous events that may cause destruction at a large scale. The hilly slopes with unconsolidated soil strata may cause landslides by shaking and rupture of ground (Jadoon et al., 2015). In this regard, fault lines were extracted from the Geological Survey of Pakistan (2004) (Sheet No. 43, G/14, Scale 1:50,000) and tectonic map (Fig. 1). Total four classes were made with the distance of $200 \mathrm{~m}$ from fault lines by using multi ring buffer tool and ranges of classified classes are 0-200 m, 201-400 m, 401-600 m, 601-800 m (Fig. 4h). Moreover, a seismic activity like an earthquake is also one of the major tectonic activity that can trigger a very sever hazardous event in any part of the world. In the vicinity of the study area, a major earthquake in tectonically active zones occurred in past that caused the occurrence of very destructive landslides. For this study, the impact earthquakes were incorporated by using earthquake data gathered from USGS as shown in Figure 1. The Kashmir earthquake occurred in 2005 with a magnitude of 7.6 and Pattan earthquake occurred in 1974 with a magnitude of 6.0 , both of these earthquakes caused a huge loss of human life, infrastructures and triggered the number of major destructive landslides (Riaz et al., 2018). Therefore, earthquake points were demarcated near the vicinity of the study area and classes were classified with respect to intensity. The classified classes are ranged from X- IX, VIII-VI, VI-IV and III-I according to the values of earthquake magnitude.

\section{LANDUSE LANDCOVER (LULC)}

Landuse landcover (LULC) is one of the most important causative factors of landslides in the study area. Landcover control the occurrence of landslide along with other parameters e.g. slope, geology, seismology (Malek et al., 2015). Vegetation provides support for the stability of landslides and rock/soil strata can cause in triggering of landslides (Reichenbach et al., 2014). Various researchers used satellite imagery to develop landuse landcover maps by using maximum likelihood (ML) supervised classification tool in computer aided programs (Escape et al., 2013; Butt et al., 2015; Rwanga and Ndambuki, 2017). Landsat 8 Satellite image of the study area was downloaded from the USGS database and orthorectified by using the QGIS 2.18 tool of semi-automatic classification plug-in (SCP). Furthermore, Satellite images were characterized by using maximum likelihood (ML) supervised classification tool of ArcGIS and the spectral signature file was generated for a total four classes of landcover. Finally, landuse landcover map have been generated by satellite images, Google earth images, toposheets, field verification and total of four classes were identified that included Vegetation, Soil/Rock, Water, 
Urban (Fig. 4i). The final landcover map was prepared by the verification of the developed landcover map with google earth image and the confusion matrix method was used for map validation. Most of the slopes in the study area are comprised of vegetation that increases the strength of subsurface soil. In study area strata of bare rock/soil is declared as most prone to landslides events and validation of map depicted that maximum landslides occurred in bare soil/rock strata.

\subsubsection{WEIGHTED OVERLAY METHOD}

Susceptibility maps can be produced by using a weighted overlay method (WOM) tool of ArcGIS. Several researchers produced susceptibility maps by using a weighted overlay method (WOM) (Intarawichian and Dasananda, 2010; Basharat et al., 2016; Shit et al., 2016; Roslee et al., 2017; Ali et al., 2019). In this study, raster files of all causative factors were developed and reclassified by assigning weights in the light of the intensity of importance determined by AHP (Table 2). Finally, all reclassified layers were combined by using WOM in ArcGIS based on this equation:

$\mathbf{S}=\frac{\sum \mathbf{W}_{\mathbf{i}} \mathbf{S}_{\mathrm{ij}}}{\sum \mathbf{W}_{\mathbf{i}}}$

Where, $S_{i j}=$ Sublass weight of $j$ th factor, $W_{i}=$ Weight of ith factor, $\mathrm{S}=$ Spatial unit for the final map

\section{RESULTS AND DISCUSSIONS}

In this study, a landslide susceptibility map is prepared by using the multi-criteria decision making, AHP and WOM methods based on the assessment of ten causative factors. In this regard, a road stretch of 71.4 kilometers was studied from Kotli to Tata Pani $(29 \mathrm{~km})$, Tata Pani to Hajira $(26.4 \mathrm{~km})$ and Hajira to Trar Khel $(16 \mathrm{~km})$. Several areas pose active zones related to landslides and slopes instability during heavy rainfall and increase of water level in the season of snowmelt. As a result of natural hazards, blockage of roads and interruption in traffic flow may cause severe problems for inhabitants. A total of 59 landslides were identified along the road sections and assessment of the slope instability mechanism and causative factors was also made by visual observation and judgement of the slope instability features and information gathered from the locals. Moreover, thematic maps of all causative factors (aspects, fault, lithology, drainage density, curvature, distance to roads, landuse landcover, slope, seismic, elevation) were prepared by incorporating data from the literature, field visits, satellite images, DEM in ArcGIS and other computer aided programs. Resolution $(12.5 \mathrm{~m} \times 12.50 \mathrm{~m})$ is one of the limitation for this study because most of the cut slopes were missed to record for the study area. The weights of all causative factors were assigned based on spatial analysis and AHP technique for the development of the final landslide susceptibility map. The pair wise comparison of subclasses of all factors was performed and tabulated in Table 2. The method of Saaty was used to determine the consistency ratio (CR) by using the Random consistency index (RI) with respect to the total number of causative factors (n). The calculated values of $\mathrm{CR}$ for all subclasses of factors are found lower than 0.10 . It represents that matrix used for pairwise comparison is consistent with reliable assessments. Finally, the pair-wise comparison of all ten major factors in triggering landslides was made on the basis of the AHP method and a consistency ratio value of 0.084 (Table 3) was determined that is remained below than 0.10 and shows the consistency in comparison based on reliable expert assessments. In this study, spatial analysis, expert opinion and field observations revealed that faults, slopes and LULC are the contributing factors in landslide occurrences, therefore, the highest weights are assigned to these factors followed by other controlling factors (aspects, lithology, drainage density, curvature, distance to roads, seismic, elevation).

Landslide susceptibility map was prepared by joining all raster layers using a weighted overlay method in GIS based on the calculated weights of all factors by AHP. The assigned weightage of classes for each causative factor is given in Table 2 and the cumulative weightage of all causative factors is tabulated in Table 3. The spatial analysis, pairwise comparison of the matrix and expert opinion revealed that fault, slope, geology and landuse landcover are the main factors to trigger landslides. Only lower values of the matrix are given in Tables 2, 3 because according to AHP upper values are the reciprocal of the lower matrix section. The highest weight of 21.09 was assigned to the factor of fault, 20.34 to slopes and weight of 20.12 was assigned to landuse landcover. The consistency index (CI) for assigned ratings to causative factors was used to calculate the consistency ratio $(\mathrm{CR})$ and the calculated values of $\mathrm{CR}$ were remained less than 0.10 that represents the consistency in the assigned ratings. Finally, the reclassified thematic layers were used for the production of landslide hazard zonation map. The resultant map of six susceptibility layers (Table 4) was reclassified in four susceptible zones and named as low susceptible, moderate susceptible, high susceptible and very high susceptible (Fig. 6a). The area of all four susceptible zones was calculated as low to moderate susceptibility zones covered an area of $39.63 \%$ and $37.29 \%$. Similarly, the area of $18.10 \%$ and $4.99 \%$ represent zones of high susceptible to very high susceptible (Fig. 6b).

In this study, 40 locations of landslides were used for spatial analysis and 19 landslide locations were used to validate the map. ROC and LDA techniques are used for the accuracy assessment of the susceptibility map. The tool of the tabulated area in GIS was used to determine the landslide densities of respective classes (Table 4). The results predicted that most of the landslides were marked in areas of high 

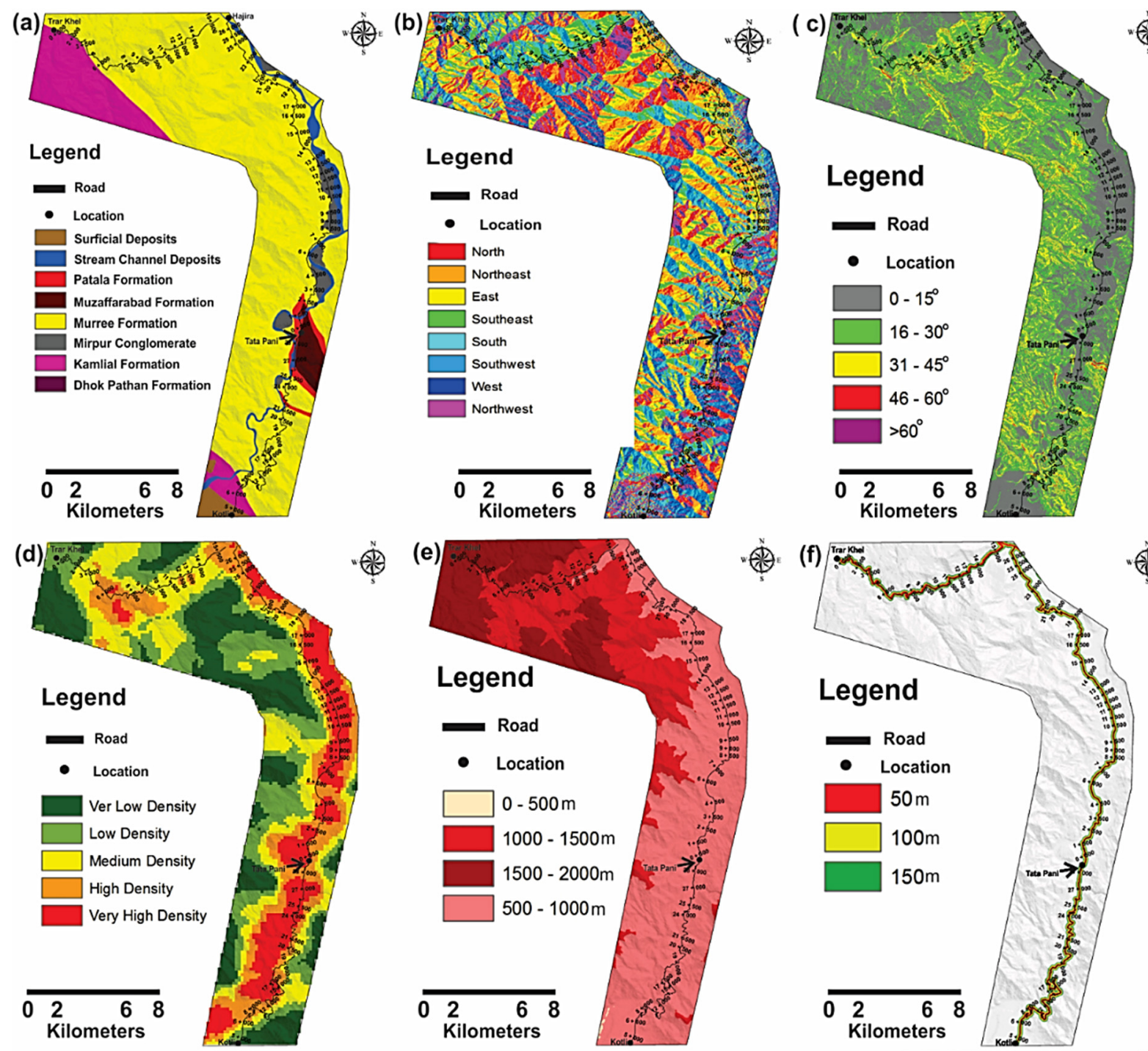

雨,
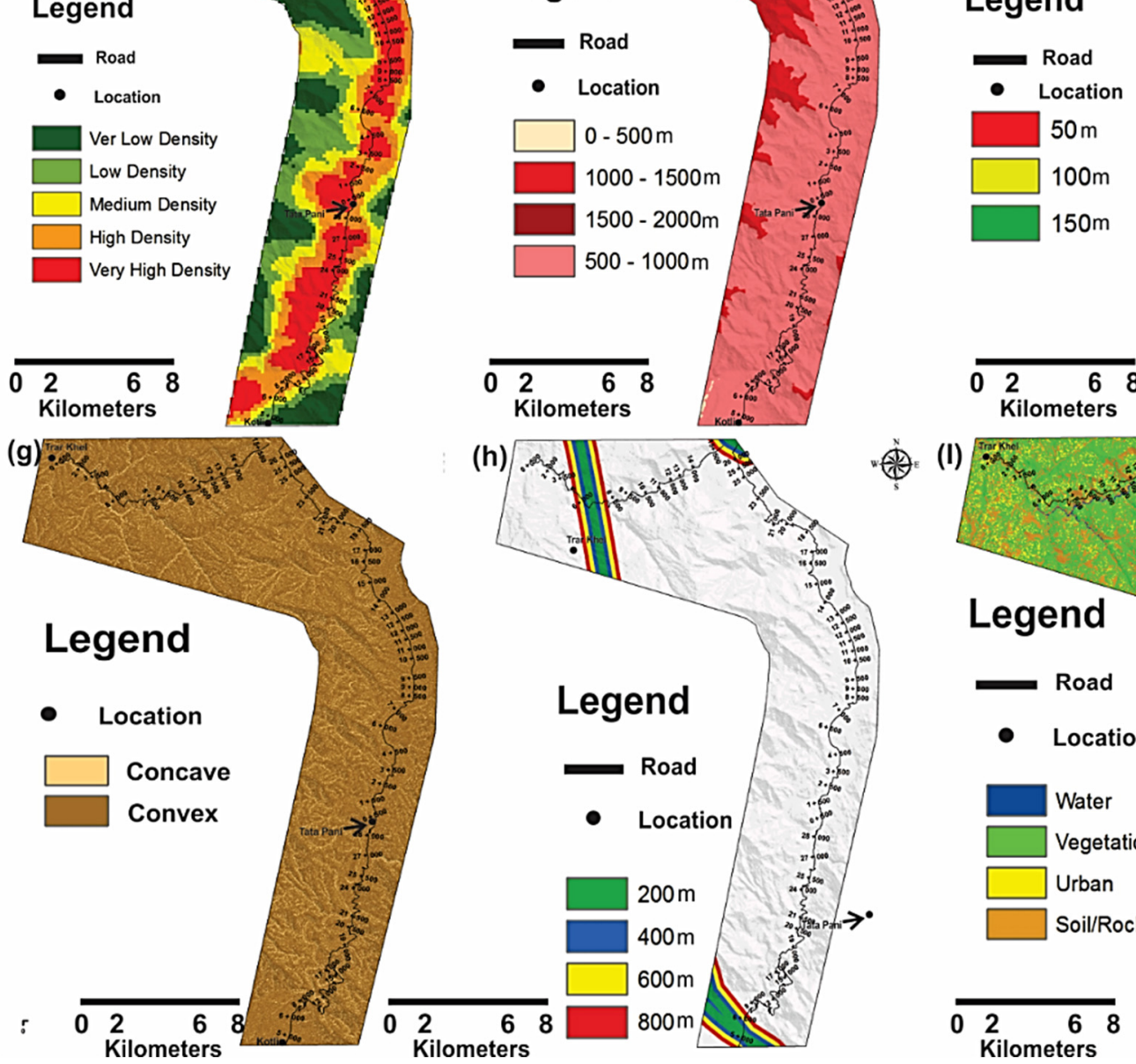

舟: (I)

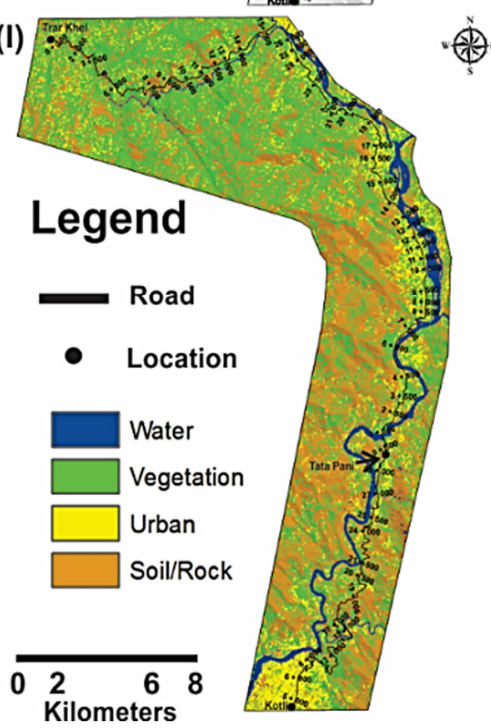

Fig. 4 Thematic layers of landslide controlling factors: (a) lithology, (b) slope aspects, (c) slope degree, (d) drainage density, (e) elevation, (f) distance to roads, (g) curvature, (h) distance to faults, (i) landuse landcover cover. 


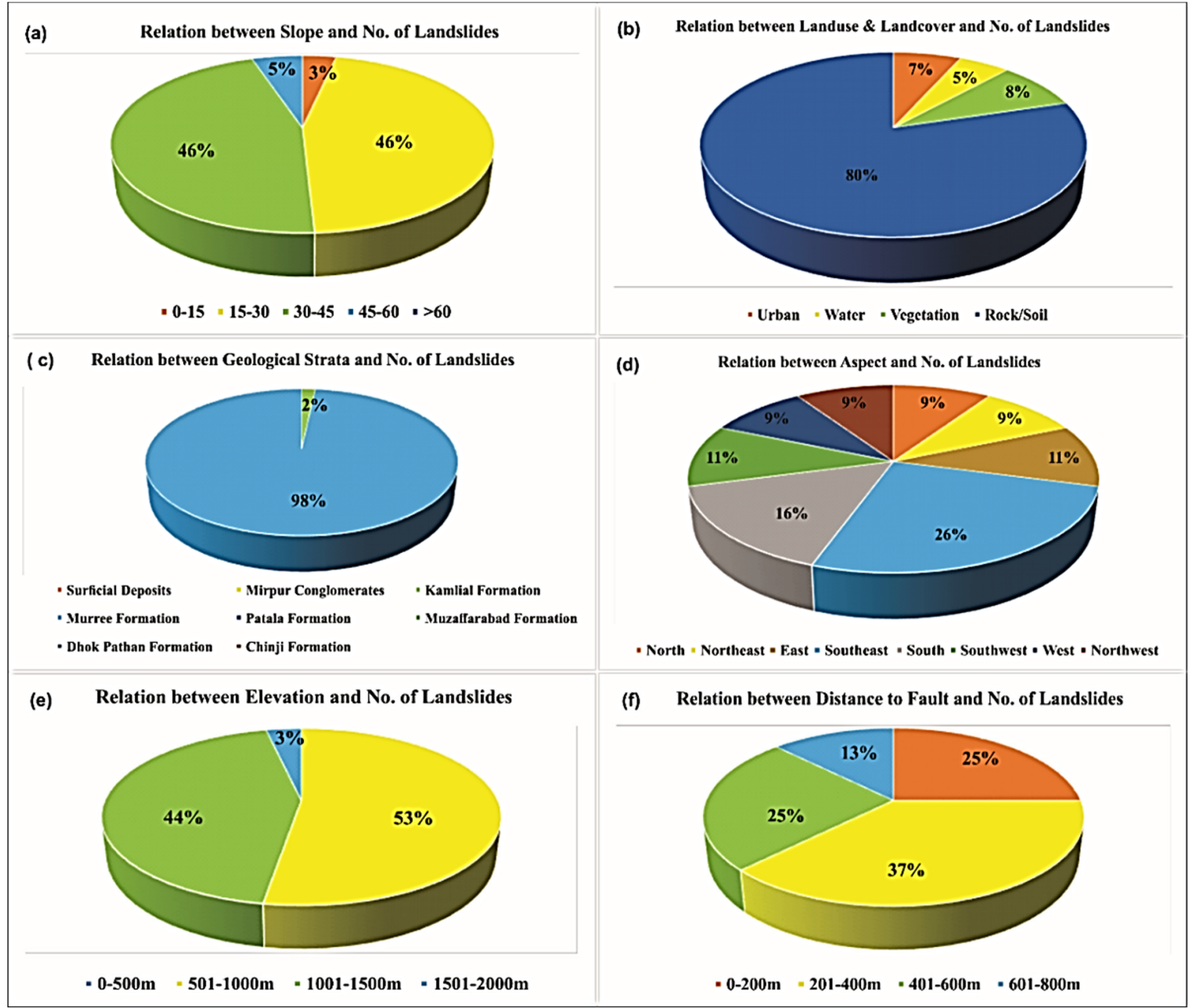

Fig. 5 Relation of landslide occurrence frequency and controlling factors: (a) Slope, (b) Landuse landcover, (c) Geological strata, (d) Aspect, (e) Elevation, (f) Distance to fault.

Table 4 Total numbers of landslides with respect to susceptibility classes and areas.

\begin{tabular}{ccc}
\hline $\begin{array}{l}\text { Susceptibility } \\
\text { Level }\end{array}$ & $\begin{array}{c}\text { No. of } \\
\text { Landslides }\end{array}$ & Area $\left.\mathbf{( k m}^{\mathbf{2}}\right)$ \\
\hline 1 & 0 & 0.906635 \\
2 & 0 & 88.50406 \\
3 & 10 & 84.13185 \\
4 & 20 & 40.83587 \\
5 & 25 & 11.09086 \\
6 & 4 & 0.170648 \\
\hline
\end{tabular}

and very high susceptibility and few landslides were located in moderate to low susceptible areas. The results showed that most of the landslides are fall towards high susceptible zones that predicted strong agreement with the accuracy of the map. Many researchers (Pradhan et al., 2010; Ahmed, 2015; Lee and Dan, 2015; Shahabi and Hashim, 2015; Basharat et al., 2016; Deng et al., 2017; Ali et al., 2019) used ROC technique to validate the map accuracy assessment. Therefore, in this study ROC is also used to predict the accuracy of the map by using a graphical plot of true positive rate (TPR) and false positive rate (FPR). Moreover, correctly predicted landslides are plotted on $\mathrm{y}$-axis as TPR and falsely predicated landslides are plotted on $\mathrm{x}$-axis as FPR. The efficiency of the model can also be determined by the Area under curve (AUC) in a graphical plot. AUC may range between 0.5 to 1.0 based on the accuracy of the model, the model will be ideal if the graphical plots show the curve/ values close to 1.0 and if the trend of values are towards 0.5 it shows random results/inaccuracy (Nandi and Shakoor, 2010; Kumar and Anbalagan, 2016; Ali et al., 2019). In this study, AUC was found 0.77 (77\%) accuracy (Fig. 7) and previous researchers rate this value as a satisfactory relation of susceptibility map. 


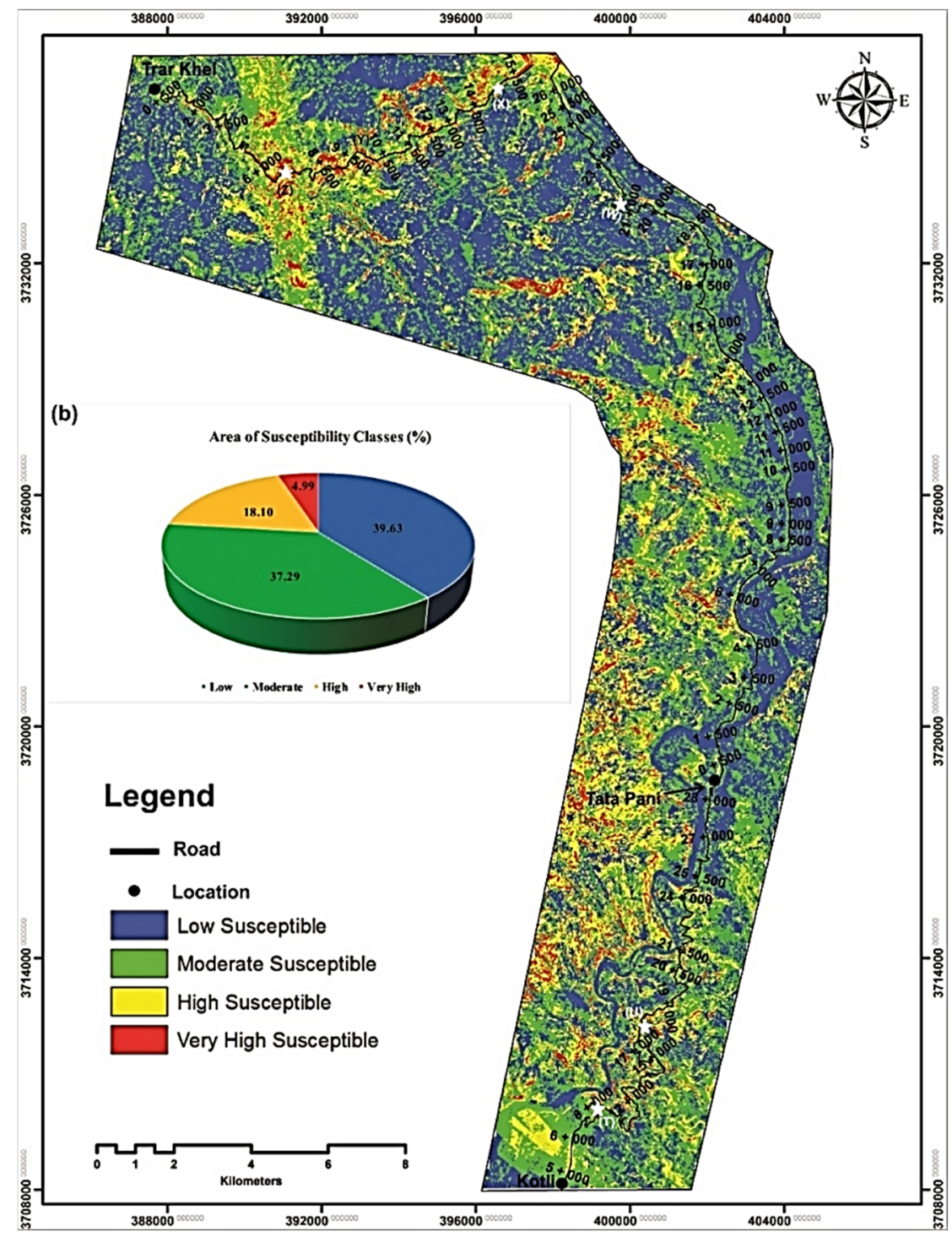

Fig. 6 (a) Landslide susceptibility map (Area with symbol (star) "T,U,W,X,Y,Z" is shown in Fig. 3), (b) Total numbers of landslides with respect to susceptibility classes and areas.

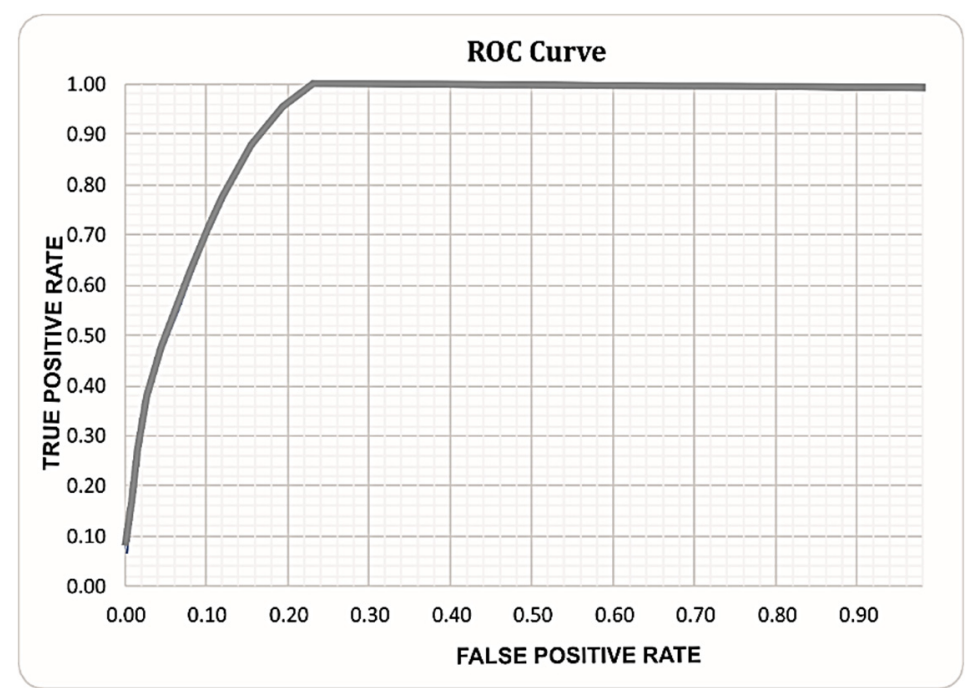

Fig. 7 Accuracy assessment of susceptibility map by receiver operating curve (ROC) and area under curve (AUC). 


\section{CONCLUSIONS}

The landslide susceptibility map of the study area along the road stretch of Kotli to Trar Khel, NW SubHimalayas, Azad Kashmir were examined by using the analytic Hierarchy Process (AHP) and weighted overlay method (WOM). The thematic layers of ten causative factors including aspects, fault, lithology, drainage density, curvature, distance to roads, landuse landcover, slope, seismic and elevation were prepared by using computer aided program GIS. Each factor was assigned by numerical weights with respect to their relative importance to trigger the landslide that was based on spatial analysis, expert opinion and best observations. The final susceptibility map was classified into four categories according to their hazardous effects: very high susceptible, high susceptible, moderate susceptible and low susceptible. Total fifty nine landslides were identified in the study area during the field visit and by using Landsat imageries. The final susceptibility map depicted that $23 \%$ area marked as high to very high susceptible and the majority of landslide identified in these zones due to prevailing weak geological strata of Murree Formation, active faults, landuse \& landcover, degree of slopes and seismic activities. Moreover, human construction near weak/disturbed overburden strata, steep slopes and in the vicinity of active faults of these zones are unsafe and may cause loss of lives due to destruction in the future. Moreover, $37 \%$ area of moderate susceptible zone can be developed for construction with the recommendation of geotechnical engineer and a low susceptible zone of $40 \%$ area may consider as safe for development due to gentler slopes and high vegetation etc. The predicted accuracy of $77 \%$ by ROC and AUC validate a good relation between assessed susceptible zones and landslide occurrence. This study provides sufficient information for government planning departments, engineers and the public to save lives and construction damages by proper remedial measurements for hazardous zones.

\section{REFERENCES}

Ahmed, B.: 2015, Landslide susceptibility mapping using multicriteria evaluation techniques in Chittagong Metropolitan Area, Bangladesh. Landslides, 22, 10771095. DOI: 10.1007/s10346-014-0521-x

Ahmed, M.F., Rogers, J.D. and Ismail, E.H.: 2014, A regional level preliminary landslide susceptibility study of the upper Indus river basin. Eur. J. Remote Sens., 47, 343-373. DOI: 10.5721/EuJRS20144721

Akgun, A., Dag, S. and Bulut, F.: 2008, Landslide susceptibility mapping for a landslide-prone area (Findikli, NE of Turkey) by likelihood frequency ratio and weighted linear combination models. Environ. Geol., 54, 1127-1143. DOI: $10.1007 / \mathrm{s} 00254-007-0882-8$

Aleotti, P. and Chowdhury, R.: 1999, Landslide hazard assessment: summary: summary review and new perspectives. Bull. Eng. Geol. Environ., 58, 21-44. DOI: $10.1007 / \mathrm{s} 100640050066$
Ali, S., Biermanns, P., Haider, R. and Reicherter, K.: 2019, Landslide susceptibility mapping by using a geographic information system (GIS) along the China-Pakistan Economic Corridor (Karakoram Highway), Pakistan. Nat. Hazard Earth Sys., 19, 9991022. DOI: 10.5194/nhess-19-999-2019

Awawdeh, M.M., Elmughrabi, M.A. and Atallah, M.Y. 2018, Landslide susceptibility mapping using GIS and weighted overlay method: a case study from North Jordan. Environ. Earth Sci., 77, 732. DOI: $10.1007 / \mathrm{s} 12665-018-7910-8$

Bacha, A.S., Shafique, M. and van der Werff, H.: 2018, Landslide inventory and susceptibility modelling using geospatial tools, in Hunza-Nagar valley, Northern Pakistan. J. Mt. Sci.-Engl., 15, 1354-1370. DOI: $10.1007 / \mathrm{s} 11629-017-4697-0$

Basharat, M., Shah, H.R. and Hameed, N.: 2016, Landslide susceptibility mapping using GIS and weighted overlay method: a case study from NW Himalayas, Pakistan. Arab. J. Geosci., 9, 292. DOI: $10.1007 / \mathrm{s} 12517-016-2308-\mathrm{y}$

Basharat, M. and Rohn, J.: 2015, Effects of volume on travel distance of mass movements triggered by the 2005 Kashmir earthquake, in the northeast Himalayas of Pakistan. Nat. Hazards, 77, 273-292. DOI: $10.1007 / \mathrm{s} 11069-015-1590-4$

Basharat, M., Rohn, J., Baig, M.S. and Ehret, D.: 2012, Lithological and structural control of Hattian Bala rock avalanche triggered by the Kashmir earthquake 2005, NW Himalaya, Pakistan. J. Earth Sci., 23, 213224. DOI: $10.1007 / \mathrm{s} 12583-012-0248-3$

Butt, A., Shabbir, R., Ahmad, S.S. and Aziz, N.: 2015, Land use change mapping and analysis using Remote Sensing and GIS: A case study of Simly watershed, Islamabad, Pakistan. Egypt. J. Remote Sens. Space Sci., 18. DOI: 10.1016/j.ejrs.2015.07.003

Cano, M. and Tomás, R.: 2013, Characterization of the instability mechanisms affecting slopes on carbonatic Flysch: Alicante (SE Spain), case study. Eng. Geo., 156, 68-91. DOI: 10.1016/j.enggeo.2013.01.009

Chacon, J., Irigaray, C., Fernandez, T. and Hamdouni, R.: 2006, Engineering geology maps: landslides and geographical information systems. Bull. Eng. Geol. Environ., 65, 341-411. DOI: $10.1007 / \mathrm{s} 10064-006-0064-\mathrm{z}$

Chalkias, C., Ferentinou, M. and Polykretis, C.: 2014, GISbased landslide susceptibility mapping on the Peloponnese peninsula, Greece. Geosciences, 4, 176190. DOI: $10.3390 /$ geosciences 4030176

Cruden, D.M. and Varnes, D.J.: 1996, Landslide types and processes. Transportation Research Board, National Academy of Sciences, 36-75.

Demir, G., Aytekin, M., Akgün, A., Ikizler, S.B. and Tatar, O.: 2013, A comparison of landslide susceptibility mapping of the eastern part of the North Anatolian Fault Zone (Turkey) by likelihood-frequency ratio and analytic hierarchy process methods. Natural Hazards, 65, 1481-1506. DOI: 10.1007/s11069-012-0418-8

Deng, X., Li, L. and Tan, Y.: 2017, Validation of spatial prediction models for landslide susceptibility mapping by considering structural similarity. ISPRS Int. J. GeoInf., 6, 103. DOI: 10.3390/ijgi6040103

Dunning, S.A., Mitchell, W.A., Rosser, N.J. and Petley, D.N.: 2007, The Hattian Bala rock avalanche and associated landslides triggered by the Kashmir earthquake of 8 October 2005. Eng. Geol., 93, 130144. DOI: $10.1016 /$ j.enggeo.2007.07.003 
Erener, A., Mutlu, A. and Sebnem, D.H.: 2016, A comparative study for landslide susceptibility mapping using GIS-based multi-criteria decision analysis (MCDA), logistic regression (LR) and association rule mining (ARM). Eng. Geol., 203, 4555. DOI: 10.1016/j.enggeo.2015.09.007

Escape, C.M., Alemania, M.K., Luzon, P.K. and Felix, R.: 2013, Comparison of various remote sensing classification methods for landslide detection using ArcGIS. https://center.noah.up.edu.ph/comparison-ofvarious-remotesensing-classification-methods-forlandslide-detection-usingarcgis

Feizizadeh, B. and Blaschke, T.: 2011, Landslide risk assessment based on GIS multi-criteria evaluation: a case study in Bostan-Abad county, Iran. J. Earth Sci. Eng, 1:66-71.

Fell, R., Corominas, J., Bonnard, C., Cascini, L., Leroi, E. and William, Z.S.: 2008, Guidelines for landslide susceptibility, hazard and risk zoning for land use planning. Eng. Geo., 102, 85-98. DOI: $10.1016 /$ j.enggeo.2008.03.022

Gawali, P.B., Aher, S.P., Lakshmi, B.V., Gaikwad, R.D., Deendayalan, K., Hanamgond, P.T., Babu, J.L.V.M., Arote, S.A. and Bairage, S.A.: 2017, Identification of landslide susceptible villages around Kalsubai region, Western Ghats of Maharashtra using geospatial techniques. J. Geol. Soc. India, 90, 301-311. DOI: $10.1007 / \mathrm{s} 12594-017-0718-4$

Goetz, J.N., Brenning, A., Petschko, H. and Leopold, P.: 2015, Evaluating machine learning and statistical prediction techniques for landslide susceptibility modeling. Comput. Geosc., 81, 1-11. DOI: $10.1016 /$ j.cageo.2015.04.007

Intarawichian, N. and Dasananda, S.: 2010, Analytical hierarchy process for landslide susceptibility mapping in lower Mae Chaem watershed, Northern Thailand, Suranaree. J. Sci. Technol., 17, 277-292.

Jadoon, I.A.K., Hinderer, M., Kausar, A.B., Qureshi, A.A., Baig, M.S., Basharat, M. and Frisch, W.: 2015, Structural interpretation and geo-hazard assessment of a locking line: 2005 Kashmir earthquake, western Himalayas. Environ. Earth Sci., 73, 7587-7602. DOI: $10.1007 / \mathrm{s} 12665-014-3929-7$

Kamp, U., Growley, B.J., Khattak, G.A. and Owen, L.A.: 2008, GIS-based landslide susceptibility mapping for the 2005 Kashmir earthquake region. Geomorphology, 101, 631-642. DOI: 10.1016/j.geomorph.2008.03.003

Kanwal, S., Atif, S. and Shafiq, M.: 2016, GIS based landslide susceptibility mapping of northern areas of Pakistan, a case study of Shigar and Shyok Basins. Geomat. Nat. Haz. Risk., 5705, 1-19. DOI: 10.1080/19475705.2016.1220023

Kavzoglu, T., Sahin, E.K. and Colkesen, I.: 2014, Landslide susceptibility mapping using GIS-based multi-criteria decision analysis, support vector machines, and logistic regression. Landslides, 11, 425-439.

DOI: $10.1007 / \mathrm{s} 10346-013-0391-7$

Kayastha, P., Dhital, M.R. and de Smedt, F.: 2013a, Evaluation and comparison of GIS based landslide susceptibility mapping procedures in Kulekhani Watershed, Nepal. J. Geol. Soc. India, 81, 219-231. DOI: $10.1016 /$ j.cageo.2012.11.003

Kayastha, P., Dhital, M.R. and de Smedt, F.: 2013b, Application of the analytical hierarchy process (AHP) for landslide susceptibility mapping: A case study from the Tinau watershed, west Nepal. Comput. Geosci., 52, 398-408. DOI: $10.1007 / \mathrm{s} 12594-013-0025-7$

Khan, H., Shafique, M., Khan, M.A., Bacha, M.A., Shah, S.U. and Calligaris, C.: 2019, Landslide susceptibility assessment using Frequency Ratio, a case study of northern Pakistan. Egypt J. Remote Sens. Space Sci., 22, 11-24. DOI: 10.1016/j.ejrs.2018.03.004

Kumar, A., Sharma, R.K. and Bansal, V.K.: 2018, Landslide hazard zonation using analytical hierarchy process along National Highway-3 in mid Himalayas of Himachal Pradesh, India. Env. Earth Sci., 77, 719. DOI: $10.1007 / \mathrm{s} 12665-018-7896-2$

Kumar, R. and Anbalagan, R. 2016. Landslide susceptibility mapping using analytical hierarchy process (AHP) in Tehri Reservoir Rim Region, Uttarakhand. J. Geol. Soc. India, 87:271-286. DOI: $10.1007 / \mathrm{s} 12594-016-0395-8$

Lee, S. and Dan, N.T.: 2015, Probabilistic landslide susceptibility mapping in the Lai Chau province of Vietnam: focus on the relationship between tectonic fractures and landslides. Environ Geol, 48, 778-787. DOI: $10.1007 / \mathrm{s} 00254-005-0019-\mathrm{x}$

Mahmood, I., Qureshi, S.N., Tariq, S., Atique, L. and Iqbal, M.F.: 2015, Analysis of landslides triggered by October 2005, Kashmir earthquake. PLoS Curr., 26, $1-7$.

DOI: $10.1371 /$ currents.dis.0bc3ebc5b8adf5c7fe9fd3d702d44a99 Malek, Ž., Zumpano, V., Schröter, D., Glade, T., Balteanu, D. and Micu, M.: 2015, Scenarios of land cover change and landslide susceptibility: An example from the Buzau Subcarpathians, Romania. Engi. Geo. Soci. and Ter., 5, 743-746. DOI: $10.1007 / 978-3-319-09048-1144$

Nandi, A. and Shakoor, A.: 2010, A GIS-based landslide susceptibility evaluation using bivariate and multivariate statistical analyses. Eng. Geol., 110, 1120. DOI: $10.1016 /$ j.enggeo.2009.10.001

Oh, S. and Lu, N.: 2015, Slope stability analysis under Unsaturated conditions: Case studies of rainfallinduced failure of cut slopes. Eng. Geo. 184, 96-103. DOI: $10.1016 /$ j.enggeo.2014.11.007

Petley, D.N., Dunning, S.A. and Rosser, N.J.: 2005, The analysis of global landslide risk through the creation of a database of world-wide landslide fatalities. Landslide risk management. Taylor\&Francis Group, London.

Pham, B.T., Bui, D.T., Prakash, I. and Dholakia, M.B.: 2017, Hybrid integration of Multilayer Perceptron Neural Networks and machine learning ensembles for landslide susceptibility assessment at Himalayan area (India) using GIS. Catena, 149, 5263. DOI: $10.1016 /$ j.catena.2016.09.007

Pourghasemi, H.R. and Rossi, M.: 2017, Landslide susceptibility modeling in a landslide prone area in Mazandarn Province, north of Iran: a comparison between GLM, GAM, MARS, and M-AHP methods. Theor. Appl. Climatol., 130, 609-633. DOI: $10.1007 / \mathrm{s} 12665-015-4950-1$

Pourghasemi, H.R. and Kerle, N.: 2016, Random forests and evidential belief function-based landslide susceptibility assessment in Western Mazandaran Province, Iran. Environ. Earth Sci., 75, 185. DOI: $10.1007 / \mathrm{s} 00704-016-1919-2$ 
Pradhan, B., Lee, S. and Buchroithner, M.F.: 2010, Remote sensing and GIS-based landslide susceptibility analysis and its cross-validation in three test areas using a frequency ratio model. Photogrammetrie, Fernerkundung, Geoinformation, 16, 17-32. DOI: $10.1127 / 1432-8364 / 2010 / 0037$

Psomiadis, E., Papazachariou, A., Soulis, K.X., Alexiou, D.S. and Charalampopoulos, I.: 2020, Landslide mapping and susceptibility assessment using geospatial analysis and Earth observation data. Land, 9, 133. DOI: 10.3390/land9050133

Rafek, A.G., Jamin, N.H.M., Lai, G.T., Simon, N. and Hussin, A.: 2016, Systematic approach to sustainable rock slope stability evaluation. Procedia Chem., 19, 981-985. DOI: 10.1016/j.proche.2016.03.145

Regmi, N.R., Giardino, J.R. and Vitek, J.D.: 2010, Modeling susceptibility to landslides using the weight of evidence approach: Western Colorado, USA. Geomorphology, 115, 172-187.

DOI: 10.1016/j.geomorph.2009.10.002

Reichenbach, P., Busca, C., Mondini, A.C. and Rossi, M.: 2014, The influence of land use change on landslide susceptibility zonation: The Briga catchment test site (Messina, Italy). Environ. Manage., 54, 1372-1384. DOI 10.1007/s00267-014-0357-0

Riaz, M.T., Basharat, M., Hameed, N., Shafique, M. and Luo, J.: 2018, A data-driven approach to landslidesusceptibility mapping in mountainous terrain: Case study from the Northwest Himalayas, Pakistan. Nat. Hazards Rev., 19.

DOI: 10.1061/(ASCE)NH.1527-6996.0000302

Roslee, R., Mickey, A.C., Simon, N. and Norhisham, M.N.: 2017, Landslide susceptibility analysis (Lsa) using weighted overlay method (WOM) along the Genting Sempah to Bentong highway, Pahang. Malays. J. Geosci, 1, 13-19. DOI: 10.26480/mjg.02.2017.13.19

Rwanga, S.S. and Ndambuki, J.M.: 2017, Accuracy assessment of land use/land cover classification using remote sensing and GIS. Int. J. Geosci., 08, 611-622. DOI: 10.4236/ijg.2017.84033

Saaty, T.L.: 1990, How to make a decision: The analytic hierarchy process. Eur. J. Oper. Res., 48, 9-26. DOI: 10.1016/0377-2217(90)90057-I

Saaty, T.L.: 1980, The analytic hierarchy process: Planning, priority setting, resource allocation (Decision Making Series). McGraw-Hill, New York.

Sarkar, S. and Kanungo, D.P.: 2004, An integrated approach for landslide susceptibility mapping using remote sensing and GIS. Photogramm. Eng. Remote Sens., 70, 617-628. DOI: 10.14358/PERS.70.5.617

Shafique, M., van der Meijde, M. and Khan, M.A.: 2016, A review of the 2005 Kashmir earthquake-induced landslides; from a remote sensing prospective. J. Asian Earth Sci., 118, 68-80.

DOI: $10.1016 /$ j.jseaes.2016.01.002
Shahabi, H. and Hashim, M.: 2015, Landslide susceptibility mapping using GIS-based statistical models and remote sensing data in tropical environment. Sci. Rep. 5, 9899. DOI: $10.1038 /$ srep09899

Sharma, R.K. and Mehta, B.S.: 2012, Macro-zonation of landslide susceptibility in Garamaura-SwarghatGambhar section of national highway 21, Bilaspur District, Himachal Pradesh (India). Nat. Hazards, 60, 671-688. DOI: 10.1007/s11069-011-0041-0

Shit, P.K., Bhunia, G.S. and Maiti, R.: 2016, Potential landslide susceptibility mapping using weighted overlay model (WOM). Model. Earth Syst. Environ., 21, 1-10. DOI: 10.1007/s40808-016-0078-x

Spiker, E.C. and Gori, P.L.: 2000, National landslide hazards mitigation strategy: a framework for loss reduction. Department of Interior, USGS open file report, 49.

Vallejo, G.L. and Ferrer, M.: 2011, Geological Engineering. CRC Press/Balkema, AK Leiden, Netherlands.

van Westen, C.J., van Asch, T.W.J. and Soeters, R.: 2006, Landslide hazard and risk zonation - Why is it still so difficult? Bull. Eng. Geol. Environ., 65, 167-184. DOI: $10.1007 / \mathrm{s} 10064-005-0023-0$

Wang, Q. and Li, W.: 2017, A GIS-based comparative evaluation of analytical hierarchy process and frequency ratio models for landslide susceptibility mapping. Phys. Geogr., 38, 318-337. DOI: 10.1016/j.catena.2011.01.014

Yalcin, A., Reis, S., Aydinoglu, A.C. and Yomralioglu, T.: 2011, A GIS-based comparative study of frequency ratio, analytical hierarchy process, bivariate statistics and logistics regression methods for landslide susceptibility mapping in Trabzon, NE Turkey. Catena, 85, 274-287.

DOI: 10.1016/j.catena.2011.01.014

Zhou, S., Chen, G., Fang, L. and Nie, Y.: 2016, GIS-based integration of subjective and objective weighting methods for regional landslides susceptibility mapping. Sustainability, 8, 1-15. DOI: $10.3390 / \mathrm{su} 8040334$

Zillman, J.: 1999, The physical impact of disaster. In: Ingleton, J. (Ed.), Natural disaster management. Leicester: Tudor Rose Holdings Ltd., 32. 